\title{
Mapping units based on spatial uncertainty of magnetic susceptibility and clay content
}

\author{
Daniel D.B. Teixeira ${ }^{\mathrm{a}, *}$, José Marques Jr. ${ }^{\mathrm{b}}$, Diego S. Siqueira ${ }^{\mathrm{b}}$, Vinicius Vasconcelos ${ }^{\mathrm{c}}$, \\ Osmar A. Carvalho Jr. ${ }^{\mathrm{d}}$, Éder S. Martins ${ }^{\mathrm{e}}$, Gener T. Pereira ${ }^{\mathrm{f}}$ \\ ${ }^{\text {a }}$ Center of Agrarian Sciences, University of Marília (Unimar), Brazil \\ ${ }^{\mathrm{b}}$ Department of Soils and Fertilizers, State University of São Paulo (UNESP), Research Group CSME — Soil Characterization for Specific Management, Jaboticabal, São \\ Paulo, Brazil \\ ${ }^{\mathrm{c}}$ Department of Ecology, University of Brasília (UNB), LSIE - Laboratory of Spatial Information Systems, Brasília, DF, Brazil \\ ${ }^{\mathrm{d}}$ Department of Geography, University of Brasília (UNB), LSIE — Laboratory of Spatial Information Systems, Brasília, DF, Brazil \\ e Embrapa Cerrados, Brasília, DF, Brazil \\ ${ }^{\mathrm{f}}$ Department of Exact Sciences, State University of São Paulo (UNESP), Research Group CSME - Soil Characterization for Specific Management, Jaboticabal, São Paulo, \\ Brazil
}

\section{A R T I C L E I N F O}

\section{Keywords:}

Geostatistics

Sequential Gaussian simulation

Pedometrics

\begin{abstract}
A B S T R A C T
This study aimed to use spatial uncertainty of magnetic susceptibility (MS) and clay content to improve soilmapping units. In an experimental area of 870 ha, a regular sampling grid containing 371 points was set, in which MS and clay content were assessed at a depth range of $0-0.25 \mathrm{~m}$. Using a digital elevation model and field observations, a 4440-m transect was established on the study area from hilltop to the foothill, toward the gentlest slope. Standard deviation maps based on 200 realizations of the sequential gaussian simulation measured spatial estimate uncertainties. To limit transition zones along the transect, uncertainty isolines representative of the transition between soil-mapping units were selected. Both attributes presented peaks of uncertainties near the change of mapping units, previously known. Uncertainty zones, previously delineated, ranged from 45 to $210 \mathrm{~m}$ and from 60 to $170 \mathrm{~m}$, for MS and clay content, respectively. However, after extrapolating the uncertainties to the side of the transect, amplitude changes of the uncertainty zones were observed, especially in the transition regions between landscape shape and geology. Delineation of mapping units, which incorporated the uncertainties of MS and clay content, was similar. However, due to lower cost and promptness, MS becomes the most feasible alternative. Knowing spatial uncertainties enables readjusting limits in maps of soil-mapping units and may support identification of most favorable regions for determining modal pedon representative of each unit.
\end{abstract}

\section{Introduction}

Pedological maps have great potential of contributing to increase agricultural production (Grunwald et al., 2011; Brevik et al., 2016), farming planning and modeling of environmental impacts (Rogowski and Wolf, 1994). However, potential limitations may hamper or even preclude the use, such as: (i) subjectivity, since the delimitations of limits of the mapped units depend on the experience and impressions of the mapper (Bazaglia Filho et al., 2013); (ii) lack of representation of the spatial and temporal variability patterns of soil attributes (Rogowski and Wolf, 1994); (iii) definition of arbitrary limits for distinguishing between different soil units (Phillips, 2013); and (iv) lack of detail due to scale of information (Sarmento et al., 2017).
Bazaglia Filho et al. (2013), comparing soil mapping units performed by different mappers, observed a great influence of performer on delimitation of soil management units, mainly in their limits. Studies conducted in the area of soil digital mapping (Nanni et al., 2014) also show difficulty in the accurate mapping of soil transitions. This inaccuracy in the limits of soil maps are the result of using the criteria established by the classification key, leading to the distinction between soils with similar behaviors and the combination of others with different behaviors (Phillips, 2013).

Some methods attempt to overcome these problems through the incorporation of the spatial variability of soil attributes (Siqueira et al., 2015) using hybrid mapping techniques (Legros, 2006; Vincent et al., 2018; Teixeira et al., 2017). Such methods are typically tested using

\footnotetext{
* Corresponding author

E-mail address: danielteixeira@unimar.br (D.D.B. Teixeira).
} 
validations (Mirzaeitalarposhti et al., 2017; Hengl et al., 2017) and error analysis (Cambule et al., 2014), providing only an overview of the error associated with the mapping. In this sense, techniques that assess and incorporate the uncertainties associated with information from soil maps promote an advance in knowledge of mapping errors (Castrignanò et al., 2008; Brevik et al., 2016). The identification and determination of uncertainties can be performed directly on the mapping units using fuzzy logic (Zhu, 1997) and indicative simulation techniques (Silva et al., 2015), or on soil attributes, especially by means of geostatistical simulations (Grunwald et al., 2007; Castrignanò et al., 2008; Teixeira et al., 2012; Viscarra-Rossel et al., 2014) and error propagation techniques (Hengl et al., 2014).

The uncertainties determined in soil units are used to identify the probability of certain class be correctly defined (Phillips, 2013). Its use is difficult since it is necessary the knowledge of a great number of modal pedons for its determination (Silva et al., 2015). In its turn, the uncertainty in spatial assessment of soil attributes is used for identifying sites that require increased number of samples (Teixeira et al., 2012), constructing estimating scenarios (Grunwald et al., 2007), and providing an indirect measure of the estimate quality generated at each site (Viscarra-Rossel et al., 2014). Despite the requirement for a great number of samples, mainly to meet the principles of geostatistical analysis (Isaaks and Srivastava, 1989), the sampling of soil attributes is faster, simpler and cheaper than the pedon sampling. Therefore, for soils with little vertical variation of diagnostic attributes or covariative attributes to them, spatial uncertainty of attributes is proposed in determining the uncertainty of mapping units and thus incorporate simultaneously the information about the spatial variability of soil attributes into the generated map.

The definition of the attributes to be used in the identification of uncertainties is of great importance. Silva et al. (2015) proposes the uncertainty assessment for soil diagnostic attributes (color, texture gradient, base saturation, clay and sand content and soil organic carbon). For tropical soils, soil mineralogy and clay content have great relationship with the taxonomic classes of soil (Costa et al., 1999) and directly influence the definition of mapping units (Marques Jr. et al., 2014; Siqueira et al., 2015). The magnetic susceptibility (MS) is covariative of factors and processes of soil formation, in addition to be closely related to its mineralogy (Camargo et al., 2014; Sarmast et al., 2017). The increasing use of MS is due to the simplicity and low cost in its determination (Dearing, 1994) and high relation with soil physical, chemical and mineralogical attributes (Siqueira et al., 2010). Thus, the hypothesis of this research is that the incorporation of uncertainties of soil attributes covariative of factors and processes of soil formation (MS and clay content) can assist in delineating mapping units, as well as in the readaptation of the limits between soil units, simultaneously incorporating information on spatial variability of soil attributes. In this sense, the objective was to use the spatial uncertainty of MS and clay content for improving soil-mapping units.

\section{Materials and methods}

\subsection{Description of the area and sampling}

The study area has central coordinates of $21^{\circ} 28^{\prime} 40^{\prime \prime} \mathrm{S}$ and $48^{\circ} 01^{\prime} 38^{\prime \prime} \mathrm{W}$ and is located in Guatapará city, São Paulo State, Brazil (Fig. 1a). The local natural vegetation consisted of semideciduous tropical forest. Currently, the area is cultivated with sugarcane under mechanical harvesting system for over 10 years. According to Thornthwaite (1948), the region's climate can be defined as B1rB'4a', i.e., a humid mesothermal climate with small water deficit and summer evapotranspiration lower than $48 \%$ of the annual evapotranspiration.

The area is located in a geological transition between the Basalt of the São Bento Group, Serra Geral Formation (SG), Eluvial-Colluvial Deposit (ECD) and Alluvial Deposit (AD) (IPT, 1981; Geobank, 2014) (Fig. 1b). The area presents concave (Cc) and convex (Cx) horizontal curvatures (Fig. 1c). These curvatures were identified by the SRTM information with horizontal resolution of $90 \mathrm{~m}$ and vertical precision of the order of $5 \mathrm{~m}$. Initially, a median filtering was used to remove values with variation higher than $10 \mathrm{~m}$ and data interpolation using the TOPOGRID tool, available in ArcGIS software, which is a routine based on algorithm developed in Hutchinson (1989). From the interpolated data, the geomorphometric signature (image of the horizontal curvature) was generated. Subsequently, the signature values were normalized through the division by the maximum value found producing values ranging from -1 to 1 . The negative values were considered as belonging to the convergent curvature (concave) and the positive to the divergent curvature (convex). For more details, see Vasconcelos et al. (2012).

According to the soil map (scale of $1: 12,000$ ) generated by the Centro de Tecnologia Canavieira (Sugarcane Technology Center) (Fig. 1d), the area registers five soil mapping units. These units are classified according to the Sistema Brasileiro de Classificação de Solos (SiBCS) (Santos et al., 2013) and Soil Taxonomy: LVAd (SiBCS: Latossolo Vermelho-Amarelo distrófico com textura media; Soil Taxonomy: Typic Hapludox); LVd (SiBCS: Latossolo Vermelho distrófico com textura media; Soil Taxonomy: Typic Hapludox); LVdf (SiBCS: Latossolo Vermelho distroférrico com textura argilosa; Soil Taxonomy: Typic Hapludox); LVef (SiBSC: Latossolo Vermelho eutroférrico com textura argilosa; Soil Taxonomy: Typic Eutrudox); RQod (SiBCS: Neossolo Quartzarênico órtico distrófico com textura arenosa; Soil Taxonomy: Typic Quartzipsamment).

In the experimental area was installed a regular sampling grid containing 371 points separated at minimum distances ranging from 145 to $174 \mathrm{~m}$, covering a total area of about 870 ha (Fig. 1e). The resulting sampling density ( 0.4 samples ha ${ }^{-1}$ ) is in accordance with the indication of the Procedimentos Normativos de Levantamentos Pedológicos (Normative Procedures of Soil Surveys) (Embrapa, 1995). At each point of the sampling grid, samples were collected within a depth range of $0-0.25 \mathrm{~m}$ for determining MS and clay content. This depth is used by the São Paulo State sugarcane sector in determining soil management (Teixeira et al., 2017). Thus, the protocol developed in this study can be easily incorporated in this sector without require huge changes.

With the support of the digital elevation model and field observations, one transect of $4440 \mathrm{~m}$ was identified in the study area from the top of hillside to the foothill, toward its most gentle slope (Fig. 1e). This transect includes two geological classes, both curvatures and all pedological mapping units present in the area.

\subsection{Laboratory analyses}

The MS was determined in a low frequency $(0.47 \mathrm{kHz})$ using $10 \mathrm{~g}$ of air-dried soil in a Bartington MS2 equipment coupled to a Bartington MS2B sensor (Dearing, 1994). The clay content was determined by the pipette method, using $\mathrm{NaOH} 0.1 \mathrm{~mol} \mathrm{~L}^{-1}$ as a chemical dispersant and mechanical agitation at low speed for $16 \mathrm{~h}$ (Embrapa, 1997).

\subsection{Data analysis}

\subsubsection{Descriptive statistics}

The variability of soil attributes was previously described by means of the construction of boxplot graphics as a function of the geological, geomorphological and pedological compartments. The boxplot graphics present the values of minimum, maximum, first quartile (Q1), second quartile (median), third quartile (Q3) and interquartile range (IR). Values higher than $\mathrm{Q} 3+1.5 \times(\mathrm{Q} 3-\mathrm{Q} 1)$ or lower than Q1-1.5 × (Q3 - Q1) are considered outliers.

\subsection{Geostatistical analysis}

The spatial variability of the variables was determined using the experimental variogram modeling based on the theory of regionalized variables (Isaaks and Srivastava, 1989). In this study, spherical, 

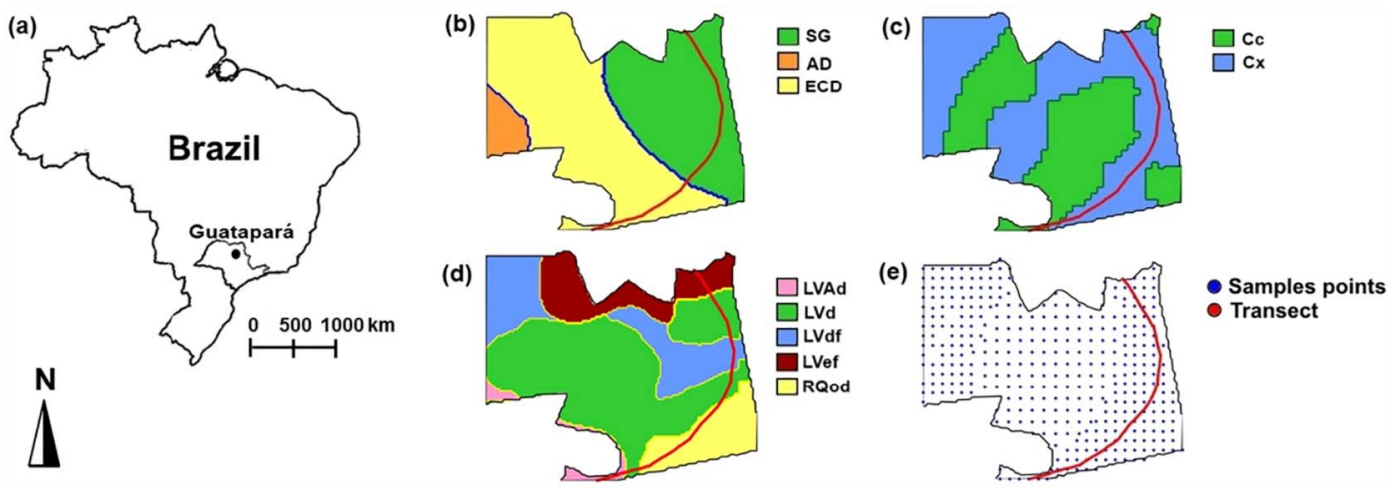

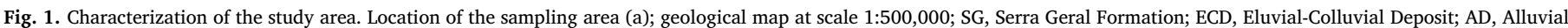

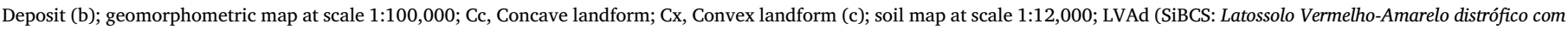

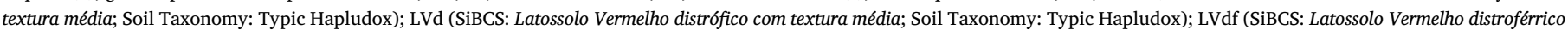

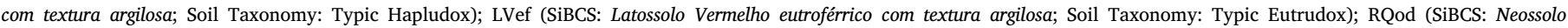
Quartzarênico órtico distrófico com textura arenosa; Soil Taxonomy: Typic Quartzipsamment)) (d); spatial distribution of the samples and transect (e).

exponential and gaussian models were tested. The choice of the model and parameters adjusted to the experimental variogram was based on the residual sum of squares (RSS), obtained during the adjustment of the theoretical model to the experimental variogram.

After the experimental variogram modeling, the estimative of attributes for locations not sampled was performed by means of sequential gaussian simulation (SGS). The SGS technique was adopted due to its characteristics of honoring the sampled values, reproducing histograms and variograms of the sample and allowing the assessment of uncertainties of the spatial patterns estimates (Grunwald et al., 2007).

For the simulation procedure, the data were previously normalized (mean and variance equal to 0 and 1 , respectively) due to the requirement of multigaussian distribution of the data. After normalization, the experimental variograms were modeled in the transformed variables (dimensionless). Subsequently, a random way able to go through all unsampled points of the refined mesh was determined. Local estimates of value and variance were performed by simple kriging, aiming the construction of the cumulative distribution function (cdf). From the cdf, considering the original neighbor values and those previously simulated, values were estimated at each point of the sampling grid. After determination of simulated values at all points in a more refined grid, the original values underwent back-transformation. Thus, the procedure was repeated until all realizations be conducted. In this study, 200 realizations of each variable were considered. The SGS procedure was based on the SGSIM routine of the Geostatistical Software Library (Deutsch and Journel, 1998).

The maps produced by SSG were generated from a refined mesh with 128 lines $\times 109$ columns, resulting in a spatial resolution of $30 \mathrm{~m}$. Maps of mean values (E-type estimates) and standard deviation were estimated from the accounting of simulated points at each location in the 200 realizations. The maps of mean values show the prevailing tendency of the attribute values in the study area as the maps of standard deviation represent the uncertainty present in the spatial estimates (Grunwald et al., 2007).

\subsection{Definition of the transition zones between mapping units}

The definition of transition zones to improve the limits of mapping units was determined based on the uncertainties of the spatial estimates of MS and clay content in locations corresponding to the transect previously demarcated (Fig. 1e). Geomorphologically, the transect is the part of the relief better preserved and thus more representative of factors and processes of soil formation. Several studies using hybrid mapping methods at a detailed level are based on the variability of soil attributes along the transect (Siqueira et al., 2015).
The uncertainty values were compared to the limits of the previously delineated mapping units. Subsequently, peak values of uncertainty were identified close to the transitions between mapping units (Fig. 1d). These peaks represent the point that populations have maximum heterogeneity and thus characterize the location with greater probability to occur the transition between soil units. For a more conservative estimate of the transition location between units, a variation of $10 \%$ of the peak value of uncertainty was taken into consideration to delimit the uncertainty zones.

After identifying the limits of the uncertainty zones in the transect previously delineated, these values were extrapolated to the transect sides using the isolines of the spatial uncertainty maps. This procedure allowed the improvement and readjustment of limits of the soil units previously mapped, incorporating information on the spatial variability of soil attributes and their spatial uncertainties.

\section{Results and discussion}

The median values of MS in the geology SG $\left(3074 \times 10^{-8} \mathrm{~m}^{3} \mathrm{~kg}^{-1}\right)$ are similar to those reported by Preetz et al. (2008) for basic and ultrabasic rocks (Fig. 2). However, these authors report MS values for sedimentary rocks below those found in this study for $\mathrm{AD}\left(1138 \times 10^{-8} \mathrm{~m}^{3} \mathrm{~kg}^{-1}\right)$ and $\operatorname{EDC}\left(1219 \times 10^{-8} \mathrm{~m}^{3} \mathrm{~kg}^{-1}\right)$. These high values of MS for AD and ECD are due to the sum of four factors: (i) the presence of iron ions in the material that suffered weathering and originated the depositional rocks; (ii) burning management of sugarcane during the previous cycles of the crop, favoring the formation of magnetite and maghemite, which have high magnetic potential (Schwertmann, 1985); (iii) entrainment of particles of the clay fraction and very fine sand from the highest parts of the relief, where the basalt soils (SG) can be found, to the lower parts (AD), promoting the redistribution of soil maghemite and magnetite content (Jong et al., 1998; Matias et al., 2014); and (iv) inefficient delineation of the geology due to the map scale adopted $(1: 500,000)$, since areas belonging to the geology SG may have been wrongly classified as belonging to the geology $\mathrm{AD}$.

The variability presented by MS in the geologies SG (CV $=81 \%)$ and $\mathrm{EDC}(\mathrm{CV}=92 \%)$ when compared to the geology $\mathrm{AD}(\mathrm{CV}=58 \%)$ is also an indicative of the detail level of the geological map and redistribution of soil maghemite and magnetite content. The lowest variability found in the geology $\mathrm{AD}$ is due to its location, bordering the geology ECD, which has similar characteristics. On the other hand, due to the abrupt transition between the magmatic rocks (SG) and more recent deposits (ECD), the variability of the limit indicated by the map influences the $\mathrm{CV}$ values.

The boxplot graphics for clay content as a function of the geological 

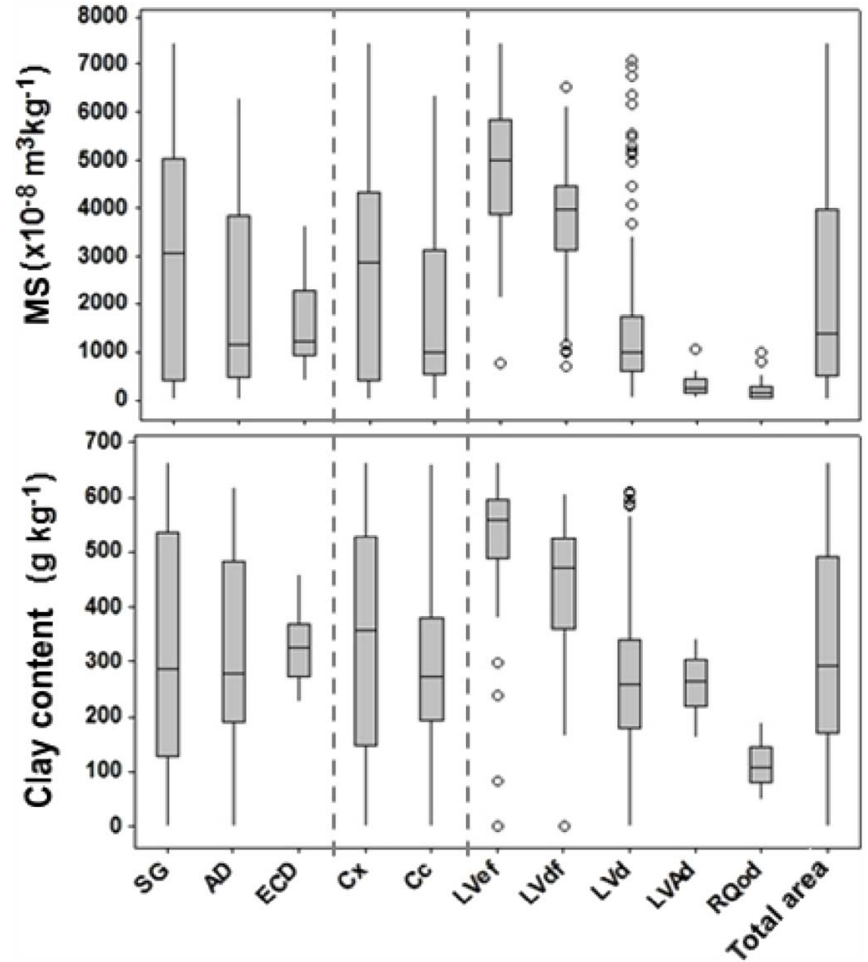

Fig. 2. Boxplot graphics of the values of magnetic susceptibility (MS) $\left(\times 10^{-8} \mathrm{~m}^{3} \mathrm{~kg}^{-1}\right)$ and clay content $\left(\mathrm{g} \mathrm{kg}^{-1}\right)$ according to the geology (SG, Serra Geral Formation; ECD, Eluvial-Colluvial Deposit; AD, Alluvial Deposit), geomorphology (Cc, concave landform; $\mathrm{Cx}$, Convex landform) and pedology (LVAd (SiBCS: Latossolo Vermelho-Amarelo distrófico com textura média; Soil Taxonomy: Typic Hapludox); LVd (SiBCS: Latossolo Vermelho distrófico com textura média; Soil Taxonomy: Typic Hapludox); LVdf (SiBCS: Latossolo Vermelho distroférrico com textura argilosa; Soil Taxonomy: Typic Hapludox); LVef (SiBCS: Latossolo Vermelho eutroférrico com textura argilosa; Soil Taxonomy: Typic Eutrudox); RQod (SiBCS: Neossolo Quartzarênico órtico distrófico com textura arenosa; Soil Taxonomy: Typic Quartzipsamment))). The lower and upper limits of the box indicates the first (Q1) and third (Q3) quartile, respectively; the line within the box indicates the median of the data; values higher than $\mathrm{Q} 3+1.5 \times(\mathrm{Q} 3-\mathrm{Q} 1)$ and lower than $\mathrm{Q} 1-1.5 \times(\mathrm{Q} 3-\mathrm{Q} 1)$ are considered outliers, being identified by circles.

units (Fig. 2) present similar behavior to that reported for MS. The median values of clay content for the geologies SG, AD and ECD were of 286, 279 and $328 \mathrm{~g} \mathrm{~kg}^{-1}$, respectively. Basalt-derived soils present texture from clayey $\left(350 \mathrm{~g} \mathrm{~kg}^{-1}<\right.$ clay content $<600 \mathrm{~g} \mathrm{~kg}^{-1}$ ) to very clayey ( $>600 \mathrm{~g} \mathrm{~kg}^{-1}$ ), as sedimentary rocks-derived soils may present texture from sandy $\left(<150 \mathrm{~g} \mathrm{~kg}^{-1}\right)$ to very clayey ( $>600 \mathrm{~g} \mathrm{~kg}^{-1}$ ) (Prado, 2013). The presence of clay content $<350$ $\mathrm{g} \mathrm{kg}^{-1}$ in an area delineated belonging to basalt indicates the influence of little detailed scale of the geological map $(1: 500,000)$.

The geomorphological compartments also influenced MS values and clay content (Fig. 2). The MS shows median values of 2878 and $995 \times 10^{-8} \mathrm{~m}^{3} \mathrm{~kg}^{-1}$ for the surfaces $\mathrm{Cx}$ and Cc, respectively. In its turn, clay content present median values of 358 and $273 \mathrm{~g} \mathrm{~kg}^{-1}$ for $\mathrm{Cx}$ and $\mathrm{Cc}$, respectively. The geomorphological compartments have indirect influence on the values of MS (Sarmast et al., 2017) and clay content, since they influence the transport of particles in the directions horizontal, via runoff (Matias et al., 2014), and vertical, by lessivage (Hanesch and Scholger, 2005). Allied to this, the geomorphological compartments also change the water dynamics in the system, altering processes of oxidation and reduction responsible by minerals neoformation with higher or lower magnetic potential (Jong et al., 2000). However, in this study the values of MS and clay content can be explained due to the greater localization of Cx surface on the geology SG. In geological transition regions, the parent material acts as the main influential factor in the MS values, since it controls the content of primary minerals resistant to weathering and those that remain in the soil (e.g. magnetite). Furthermore, the parent material coordinate the availability of iron in the soil, which will affect the neoformation of other minerals with magnetic expression (Hanesch and Scholger, 2005).

When stratifying the values of MS and clay content as a function of soil mapping units identified in the area, outlier values are observed in five soil units for MS and three soil units for clay content (Fig. 2). Outlier values are indicative of the presence of points that are not part of the same population of data than the others. The removal of outlier values is a common procedure adopted in estimating protocols of soil parameters (Batjes, 2002). However, the presence of these values can be related to the concept of taxadjunt. In this concept, pedons that do not fall into a particular taxon, but have similar characteristics in their morphology, composition and management recommendations can be grouped in the same soil class, since it does not exceed the ratio of 20 to $30 \%$ of pedons identified in the area (USDA, 1999).

In several soil units there is a strong vertical variation of soil attributes, thus the $0-0.25 \mathrm{~m}$ depth not always could be representative of the all soil layers (Fekiacova et al., 2013). This vertical variation can be characteristics of the soil unit or originated from translocations of materials in sloping areas due to erosion. Thus, the topsoil layer may not be homogeneous with the rest of soil profile and may not be representative of soil units. However, the Oxisols, mainly the ones originated from Basalt, has low vertical variation. Thus, samples collected at $0-0.25 \mathrm{~m}$ depth may be representative of the deeper layers in these soils. Siqueira et al. (2014), in an adjacent area presented in this study, verified that the spatial pattern of MS and clay content at $0-0.25 \mathrm{~m}$ and $0.25-0.50 \mathrm{~m}$ depth are similar. Also, Matias et al. (2013) evaluating the vertical variation of MS and clay content in Latossolo Vermelho Amarelo (Typic Hapludox) and Latossolo Vermelho (Typic Hapludox) verified a low variation in their contents up to $2.3 \mathrm{~m}$ depth.

Considering the low vertical variation of diagnostic attributes in Oxisols (Costa et al., 1999), we may infer that the presented values of MS and clay content partially have representativeness of pedological horizons. Thus, the knowledge of the horizontal variation in surface horizons for these soils may indicate locations with greater or lesser predisposition to taxadjunt.

When localizing spatially the outlier values previously identified in (a)

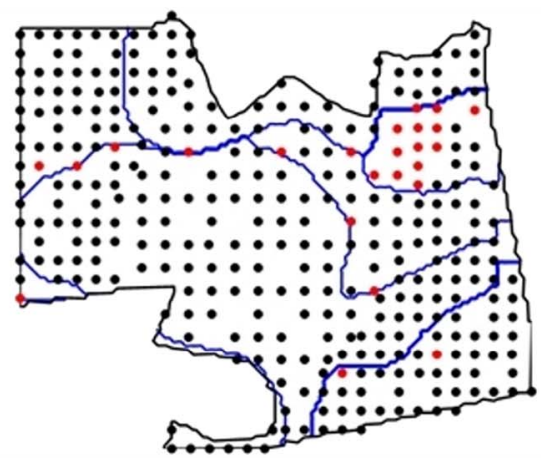

(b)

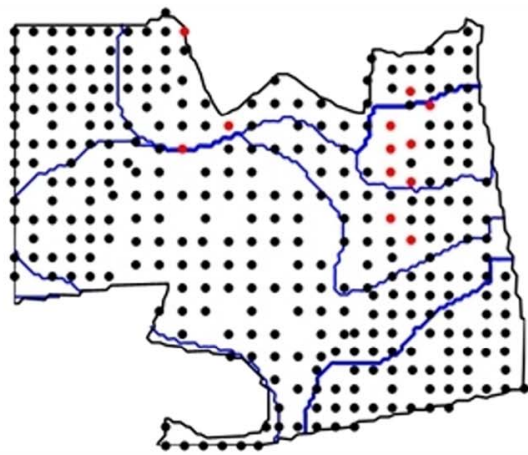

Fig. 3. Identification of outlier samples as a function of soil type. (a) Outlier values for magnetic susceptibility; (b) outlier values for clay content. 
(a)

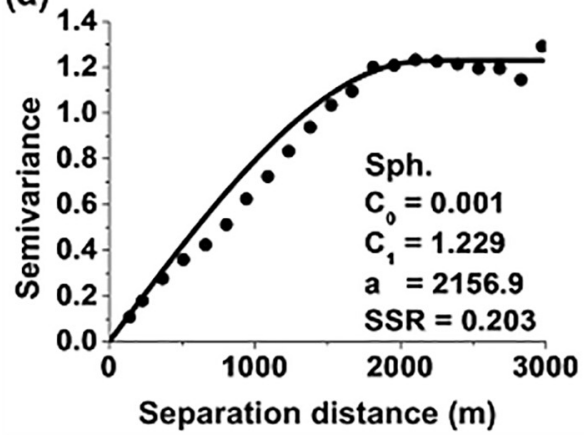

(b)

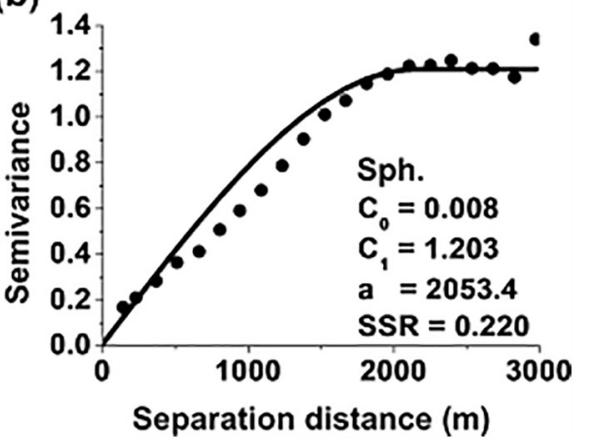

Fig. 4. Variogram models and parameters of magnetic susceptibility (MS) (a) and clay content (b). (Sph, spherical model; $\mathrm{C}_{0}$, nugget effect; $\mathrm{C}_{1}$, contribution; a, range $(\mathrm{m})$; RSS, residual sum of squares).
Fig. 2, both the points highlighted for MS (Fig. 3a) and clay content (Fig. 3b) are located mainly in the transition areas between soil units. This fact may be an indicative of the influence of the soil mapping scale (scale of $1: 12,000$ ), which although more detailed than the geological map, it also presents problems in the delineation of the limits between mapping units. The soil map is made by observation between the local geological information and those from landscape (Hudson, 1992). However, it does not provide information on the spatial variability of soil attribute (Rogowski and Wolf, 1994). Thus, the accuracy in delineating the mapping units may be affected. Information about the presence of outlier values in the limits between soil mapping units are indications that the spatial continuity of soil attributes should be considered (Siqueira et al., 2015) and can assist in refining the limit of these units. However, more refined and robust approaches, such as geostatistical analysis, should be preferred to incorporate such information in soil maps (Silva et al., 2014).

The estimates of parameters and models of variograms adjusted to the values of MS and clay content were similar (Fig. 4). The similarity between variograms reflects the high value of correlation $(r=0.92$; $p<0.01$ ) found for the attributes and reported by other authors (Siqueira et al., 2010). The spherical models, adjusted to both experimental variograms, are used for attributes with abrupt changes in space (Isaaks and Srivastava, 1989), which is the main model used to describe the spatial distribution of soil attributes (Cambardella et al., 1994).

The estimates of the model parameters indicate that although low, the value of $\mathrm{C}_{0}$ for MS $\left(\mathrm{C}_{0}=0.001\right)$ was about 8 times lower than that found for clay content $\left(\mathrm{C}_{0}=0.008\right)$. The values of $\mathrm{C}_{0}$ consist of the sum of variabilities due to measurement errors and that existent at a smaller scale than the assessed (Isaaks and Srivastava, 1989). Thus, the larger $\mathrm{C}_{0}$ to clay content may be related to errors in the procedures of particle size analysis, which vary from 15 to $32 \%$ in Brazilian laboratories (Cantarella et al., 2006). However, when estimating the degree of spatial dependence (DSD $=\mathrm{C}_{0} /\left(\mathrm{C}_{0}+\mathrm{C}_{1}\right)$ ), it is noteworthy that both have strong spatial dependence (DSD $\leq 0.25$ ) (Cambardella et al., 1994), which is associated with intrinsic factors, such as parent material, climate and relief.

The range values estimated for MS and clay content were of 2156.9 and $2053.4 \mathrm{~m}$, respectively. The range values indicate the maximum distance at which the samples present spatial dependence (Isaaks and Srivastava, 1989) and are used as an indicative of the minimum spacing for future sampling (Montanari et al., 2012; Marques Jr. et al., 2015). Thus, spatial configurations for capturing MS and clay content that include the spatial component should be similar (Siqueira et al., 2014).

The spatial patterns of mean estimates (E-type) of MS and clay content, as well as the uncertainties present in such estimates are shown in Fig. 5. It is observed similarities ( $r=0.92 ; p<0.001)$ between the spatial patterns of MS (Fig. 5a) and clay content (Fig. 5b). In both attributes, the highest values are presented in the upper right portion of the study area, located mainly on the geology SG and convex surface. In contrast, in the central portion of the area, located on the geology $\mathrm{AD}$ and concave and convex surfaces, the highest values tend to be found on the concave surface.

As discussed above, the parent material is the main influential factor in the values of MS and clay content. However, when there is no variation in the parent material, the landscape shapes begin to control the values of these attributes (Hanesch and Scholger, 2005). Thus, the transition between the influences of compartments in little detailed scale to compartments in more detailed scales is clearly seen (Miller et al., 2015). Models developed in little detailed scale involve geological and climatic variations, as models for more detailed scales involve mainly geomorphological information (Fürst et al., 2010). The isolines direction of the spatial patterns of MS and clay content reinforces the influence of geology and geomorphology in detailed mappings. It is observed that both the average value and the uncertainty are parallel to the geological limit with the basalt (upper portion of the area). In similar geological environments (AD-ECD), the variability isolines reverse their direction and remain perpendicular to the geological transition with the basalt, but parallel to the $\mathrm{Cx}$ and Cc forms (central portion of the area). This effect evidences that even little detailed geological information may assist in understanding the variability in a detailed manner in transition regions (Teixeira et al., 2017).

The uncertainties present in the estimates of MS (Fig. 5c) show a positive correlation $(r=0.35 ; p<0.001)$ with the spatial estimates of MS values (Fig. 5a). On the other hand, there was no correlation $(r=0.05)$ between the uncertainties of clay content (Fig. $5 \mathrm{~d})$ and its estimates (Fig. 5b). The presence of this weak correlation for MS is related to the strong positive skewness observed for the variable, as the absence of correlation for clay content can be explained by the variable distribution close to the normal (Fig. 2) (Castrignanò et al., 2008). The relationship between the uncertainty and skewness of the variables is due to the low probability (high uncertainty) to obtain high (positive skewness) or low (negative skewness) estimated values.

Another factor that influences the uncertainty values is the sampling density used (Grunwald et al., 2007). Thus, locations with lower sampling density are supposed to show higher uncertainty in the estimates (Delbari et al., 2009; Teixeira et al., 2012). Although in this study an irregular sampling with slightly greater spacing in the central portion of the area $(173 \mathrm{~m})$ in relation to the laterals $(150 \mathrm{~m})$ has been used, the sampling effect was not observed. Thus, a third influential factor in the spatial uncertainties (presence of transitions between compartments with different variabilities) should be predominant in the study area.

Different geologies (Hanesch et al., 2007; Preetz et al., 2008), landforms (Siqueira et al., 2010; Camargo et al., 2014) and soil units (Hanesch and Scholger, 2005; Hanesch et al., 2007; Siqueira et al., 2014) present different average values with different potential variation of soil attributes, mainly for those attributes covariatives of the factors and processes of soil formation, such as MS and clay content. Thus, when studying the uncertainties in an area with different compartments, each of them present a distinct global uncertainty related to their natural variability (Castrignanò et al., 2008). However, in regions with abrupt transitions between parent materials, landscape shapes and/or contrasting soil units, as in this study, a greater uncertainty in 
(a)

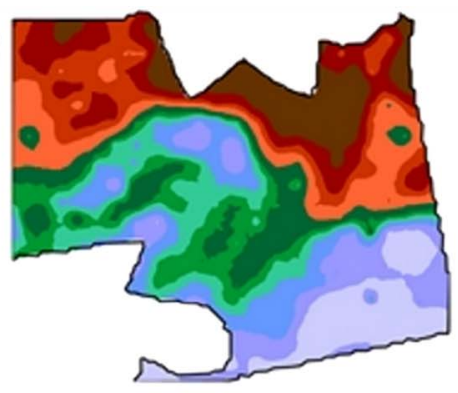

(c)

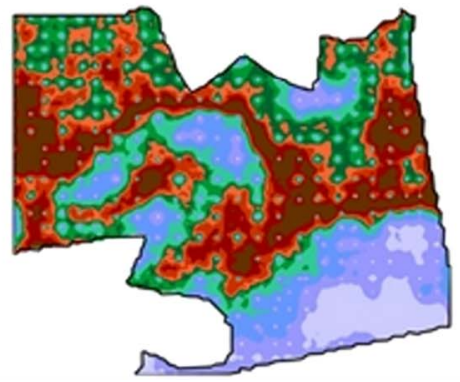

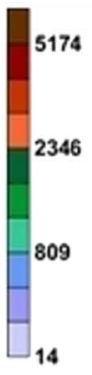

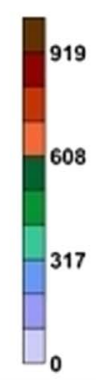

(b)

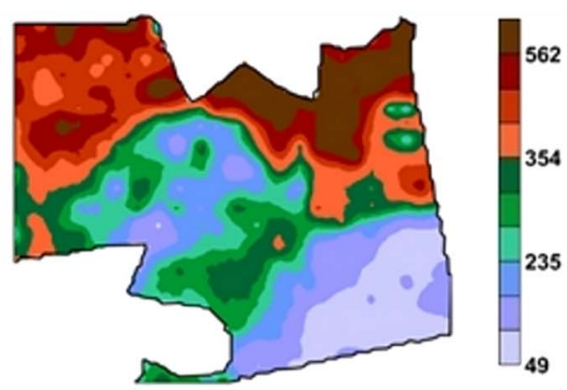

(d)

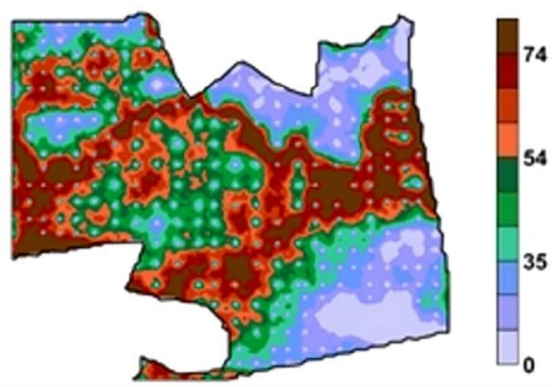

562

54

35

$\mathbf{N}$

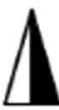

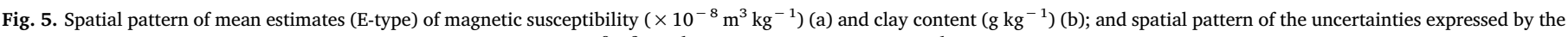
standard deviation of the estimates of magnetic susceptibility $\left(\times 10^{-8} \mathrm{~m}^{3} \mathrm{~kg}^{-1}\right)$ (c) and clay content $\left(\mathrm{g} \mathrm{kg}^{-1}\right)(\mathrm{d})$.

the estimation of the intersection region of these compartments is expected. Thus, the compartments present in the area, and mainly the transition between them, contemplate the third influential factor in the spatial uncertainties.

The spatial patterns of the uncertainties of MS and clay content presented high positive correlation $(r=0.706 ; p<0.001)$, showing that common factors (transition between compartments) are responsible for the intensity of uncertainties in both attributes. This association can be attributed to soil weathering and the presence of iron in the formation of the parent material, which favors the joint formation of the clay fraction and iron oxides with potential magnetic expression (Hanesch and Scholger, 2005). For both attributes, the regions of greater uncertainties were those where were observed transitions between geologies and landforms. These regions coincide with the transition region between soil units (Fig. 1d). This is a first indication that the uncertainties of covariatives attributes of factors and processes of soil formation can be used to identify the limits between mapping units (Odgers et al., 2015).

The mean (E-type) and uncertainties (standard deviation) values of estimates in the delineated transect in the area are shown in Fig. 6. The presence of peak values of the uncertainties of MS (Fig. 6a) and clay content (Fig. 6b) in locations close to the transition region between mapping units confirms the hypothesis that spatial uncertainties maps can be used in delineating these units. Moreover, in general, the average values of soil attributes close to these transitions have no changes. Although the clay content is used as a diagnostic attribute of soil, the limits used to define the units are arbitrary (Phillips, 2013), showing no relation to the variability of each class or spatial continuity of the attribute. On the other hand, the limits of uncertainties incorporate the inherent variability in each delineated mapping unit (Odgers et al., 2015). In addition, other peaks are observed (Fig. 6), in addition to the representative of the transition between soil units, which could be used to refine the previously prepared map of soil units and not only promote a readjusting of its limits.

The uncertainty values, expressed by the standard deviation of the estimated values between the uncertainty zones, represent the inherent uncertainty of each mapping unit. Units with greater uncertainty require more samples to their correct characterization and/or understanding of the phenomenon under study (Cambule et al., 2014; Viscarra-Rossel et al., 2014; Silva et al., 2015; Odgers et al., 2015). The clay contents present a greater variation of uncertainty within each unit when compared to MS.

The amplitude of uncertainty zones found for MS were of $45 \mathrm{~m}$ (LVef/LVd), 130 m (LVd/LVdf), 90 m (LVdf/LVd), 100 m (LVd/RQod), $210 \mathrm{~m}$ (RQod/LVd) and $100 \mathrm{~m}$ (LVd/LVAd). For clay content, the amplitudes of uncertainty zones were $70 \mathrm{~m}$ (LVef/LVd), $100 \mathrm{~m}$ (LVd/ LVdf), $60 \mathrm{~m}$ (LVdf/LVd), $130 \mathrm{~m}$ (LVd/RQod), $90 \mathrm{~m}$ (RQod/LVD) and $170 \mathrm{~m}$ (LVD/LVAd) (Fig. 6a and b). However, for both attributes studied, these amplitudes have lateral variation (Fig. 7). Regions with higher amplitude of uncertainties present higher probability of error in delineating the perimeter and occurrence of taxadjunt. Regions with geological and geomorphological transitions have higher amplitude due to the greater environment complexity. These areas include the main differences between the maps of mapping unit and uncertainty zones proposed based on MS and clay content.

The uncertainty zones identified based on MS (Fig. 6a) include 3 of the 6 transitions of soil units, being two (LVd/LVdf and LVdf/LVd) present in soils under basalt. Uncertainty zones based on clay content also include three transitions between soil units, with two (LVd/RQod and LVd/LVad) present in soils on depositional parent material (Alluvial Deposit). Thus, in regions under basalt, MS captures better the transitions between soil units; on the other hand, in regions where the soil has a depositional origin, the clay content presents results closer to those delineated by the mapper. The clay content expresses the amount present in the clay fraction; the MS, in its turn, can be considered a quality measure of the clay fraction, since it is mainly a result of the minerals present in this fraction (Siqueira et al., 2014).

Comparing the uncertainties zones of both attributes, their superposition is noted. Thus, both attributes can be used to redefine or identify the limits of the soil-mapping units. However, due to the obtainment of MS be easy and quick, in addition not to generate chemical residues during its determination (Dearing, 1994), it represents the main option in determining the mapping units considering the spatial uncertainty of the estimates.

The transition zones extrapolated laterally follow the same orientation of the limits previously identified by the map of soil units (Fig. 7). The main differences identified focus on increasing the area of the unit LVef rather than the reduction of the soil unit LVd (upper portion of the map) and the reduction of area represented by the soil unit LVad. These changes are consistent with the presence of outlier 
(a)

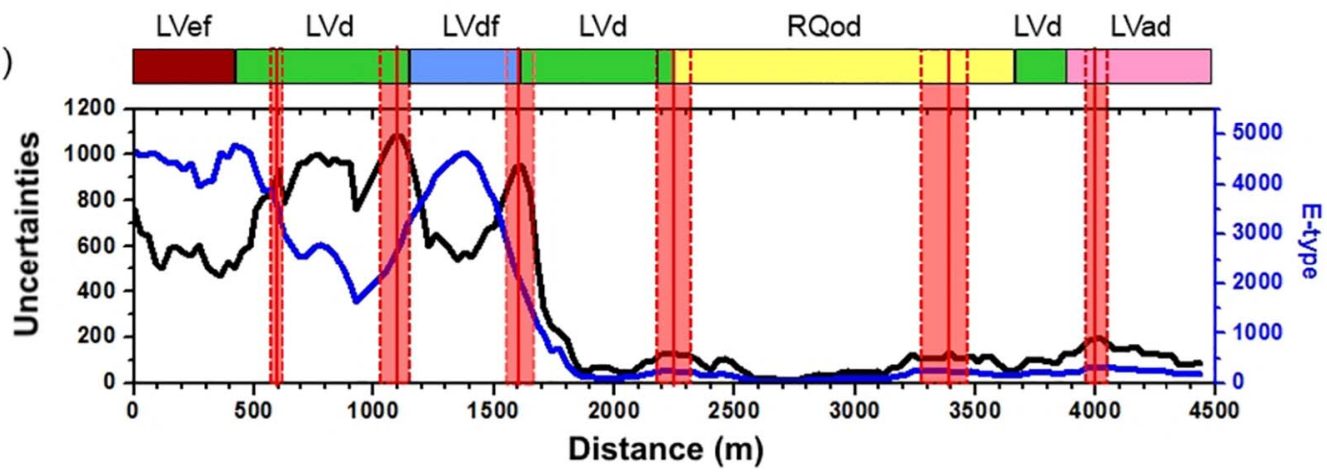

(b)

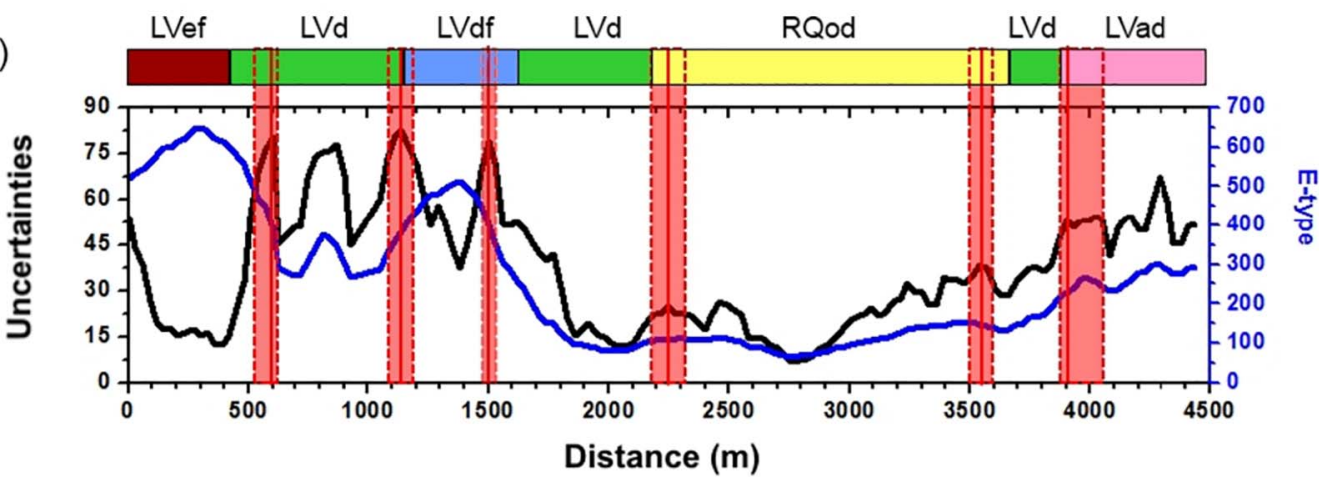

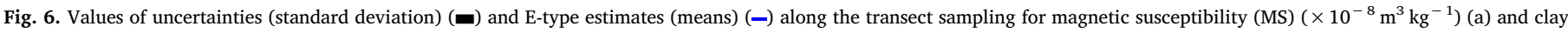

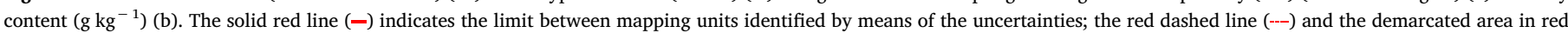
identify the uncertainty zone. (For interpretation of the references to color in this figure legend, the reader is referred to the web version of this article.)

values identified in each soil unit (Fig. 3). Thus, it is observed that with the readaptation of the proposed limits based on the uncertainties, the soil samples that presented outlier values have joined the adjacent soil units or the uncertainty zone.

The delimitation of mapping units based on uncertainties allows the identification of soils with greater or lesser uncertainty, assisting in future studies about stratified planning of soil samples (Siqueira et al., 2014). Regions with high amplitude of the uncertainty zone can be sampled intensively aiming its reduction. However, it is noteworthy that even after re-sampling, there will always be an uncertainty zone due to the complexity of the environment in the regions of transition between soil units, as reported by Bazaglia Filho et al. (2013) and Nanni et al. (2014). The knowledge of uncertainties of soil attributes can also be used to delineating management areas, being the areas belonging the uncertainty zones used as areas of vehicular traffic and maneuvering, thus avoiding the necessity of determining the management in highly variable regions. The redefinition of agricultural plots based on the variability and delineation of uncertainty ranges can improve the operating capacity since the agricultural plot can be extended in the direction of minimum variability and uncertainty, providing greater efficiency during maneuver and reduction in the machine's route time.

The protocol developed in this study demonstrates the use of uncertainties for readjusting the mapping units, since it is started from a prior knowledge about a first approximation of the map of soil units delineated in a conventional manner. However, this protocol can also be used for the identification of mapping units in areas where there is no prior knowledge. For this, after the determination of the uncertainties present in the spatial estimates, the experienced mapper could define the uncertainty lines corresponding to the transition zones between the mapping units (Odgers et al., 2015). Once delineated, it becomes possible to identify locations for the definition of modal pedons related to each mapping unit. This approach allows the economy of time and resources (Bazaglia Filho et al., 2013), often allowing the mapping of large areas.

Another advantage of delimiting mapping units using the spatial uncertainties of soil attributes is the incorporation of the spatial (a)
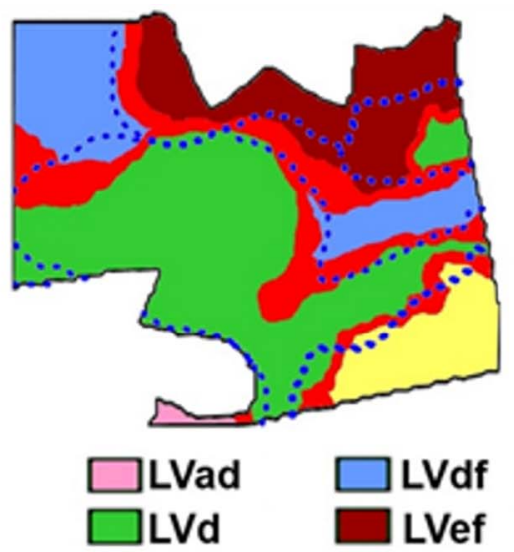

(b)

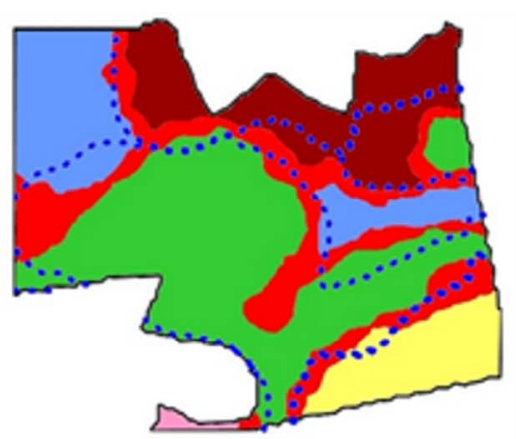

RQod

Uncertainty zone
Fig. 7. Map of mapping units proposed based on the uncertainties of magnetic susceptibility (a) and clay content (b). The dashed line (---) indicates the limits between the previously delineated units in a conventional manner. 
variability of soil attributes in the final map (Odgers et al., 2015; Silva et al., 2015). In addition to present a lack of information on spatial variability, soil maps also have a lack of information on temporal variability of soil attributes (Rogowski and Wolf, 1994; Grunwald et al., 2011). In this sense, the choice of the attribute for the delimitation of mapping units can assist with this demand.

The electrical conductivity (EC) stands out as one of the attributes most used to provide indirect information about others soil attributes (Kelley et al., 2017). The main reasons for this are the high correlations with the soil attributes and the ease in their determination, which allow on-the-go measurement. However, the EC may present instabilities in tropical soils, since it undergoes alterations in regions with high oxides presence (Wu et al., 2008) and under conditions with great variation of soil moisture. In turn, the MS does not present such instabilities, showing itself as an option to delineate mapping units with different patterns of variability (Siqueira et al., 2015). Although, there is still no methodology for on-the-go determination of MS, there are field measurement equipment, which can increase the efficiency and use of this attribute.

The MS, in addition to present spatial variability, also presents temporal variability (Maher et al., 2003). The temporal component is related to two periods (Hanesch and Scholger, 2005): (i) short-term, which is influenced by the transport of soil particles due to erosion or lessivage and soil management, which may influence the neoformation of minerals; and (ii) long-term, which is influenced by environmental characteristics due to the dynamics of water in the system that influences the oxidation and reduction processes. On the other hand, the clay content present only a short-term period component due to particle entrainment. Thus, the incorporation of uncertainties from MS maps in delineating soil-mapping units can meet the current needs of the research area (Brevik et al., 2016), incorporating information on the spatial and temporal variability of soil attributes in the delineation of mapping units.

The Oxisols are present in about 11.8 million $\mathrm{Km}^{2}$ and they are distributed mainly in the tropical regions (Eswaran and Reich, 2005), where much of the agricultural production is concentrated. Thus, the methodology developed in this study can be used in most agricultural lands. In addition, Siqueira et al. (2014) identified 44,000 ha in São Paulo State with the same characteristics of the study area, and the transfer of technology to these areas is immediate. However, in regions with other soil units, the developed methodology could also be used by means of its adaptation to the collection and analysis of soil samples at the appropriate depth to represent the soil diagnostic horizon.

\section{Conclusions}

The incorporation of information from uncertainty maps of MS and clay content in delineating mapping units allows the incorporation of information on spatial variability of soil attributes to the delineated map. The use of uncertainties of both attributes result in similar mapping units. However, the easiness, quickness and low cost in obtaining the magnetic susceptibility makes it to be the main alternative to the incorporation of spatial uncertainty in maps of mapping units.

The protocol developed in this study, in addition to enable the incorporation of spatial components in delineating mapping units, allows the identification of appropriate regions for determining the modal pedon, regions with the highest requirement of sampling and definition of management zones, identifying the most adequate areas for vehicle traffic and maneuvers of agricultural machinery.

\section{Acknowledgments}

To Coordenação de Aperfeiçoamento de Pessoal de Nível Superior (Capes) for granting a graduate scholarship to the frst author, to Conselho Nacional de Desenvolvimento Científco e Tecnológico (CNPq) for the research productivity grants for the second, fifth, sixth and seventh authors and to São Paulo Research Foundation (FAPESP) for research grants (Proc: 2013/25118-4).

\section{References}

Batjes, N.H., 2002. Soil parameter estimates for the soil types of the world for use in global and regional modeling. In: ISRIC Report 2002/02c, Version 2.1, (52 p.).

Bazaglia Filho, O., Rizzo, R., Lepsch, I.F., Prado, H., Gomes, F.H., Mazza, J.A., Demattê, J.A.M., 2013. Comparison between detailed digital and conventional soil maps of an area with complex geology. Rev. Bras. Ciênc. Solo 37 (5), 1136-1148. http://dx.doi. org/10.1590/S0100-06832013000500003.

Brevik, E.C., Calzolari, C., Miller, B.A., Pereira, P., Kabala, C., Baumgarten, A., Jordán, A., 2016. Soil mapping, classification, and pedologic modeling: history and future directions. Geoderma 264, 256-274. http://dx.doi.org/10.1016/j.geoderma.2015. 05.0.

Camargo, L.A., Marques Jr., J., Pereira, G.T., Bahia, A.S.R.S., 2014. Clay mineralogy and magnetic susceptibility of Oxisols in geomorphic surfaces. Sci. Agric. 71 (3), 244-256. http://dx.doi.org/10.1590/S0103-90162014000300010.

Cambardella, C.A., Moorman, T.B., Novak, J.M., Parkin, T.B., Karlen, D.L., Turco, R.F., Konopka, A.E., 1994. Field-scale variability of soil properties in central Iowa soils. Soil Sci. Soc. Am. J. 58 (5), 1501-1511. http://dx.doi.org/10.2136/sssaj1994. 03615995005800050033x.

Cambule, A.H., Rossiter, D.G., Stoorvogel, J.J., Smaling, E.M.A., 2014. Soil organic carbon stocks in the Limpopo National Park, Mozambique: amount, spatial distribution and uncertainty. Geoderma 213, 46-56. http://dx.doi.org/10.1016/j. geoderma.2013.07.015

Cantarella, H., Quaggio, J.A., Van Raij, B., Abreu, M.F., 2006. Variability of soil analysis in commercial laboratories: implications for lime and fertilizer recommendations. Commun. Soil Sci. Plant Anal. 37 (15-20), 2213-2225.

Castrignanò, A., Buttafuoco, G., Canu, A., Zucca, C., Madrau, S., 2008. Modelling spatial uncertainty of soil erodibility factor using joint stochastic simulation. Land Degrad. Dev. 19 (2), 198-213. http://dx.doi.org/10.1002/ldr.836.

Costa, A.C.S., Bigham, J.M., Rhoton, F.E., Traina, S.J., 1999. Quantification and characterization of maghemite in soils derived from volcanic rocks in southern Brazil. Clay Clay Miner. 47 (4), 466-473. http://dx.doi.org/10.1346/CCMN.1999.0470408.

Dearing, J.A., 1994. Environmental magnetic susceptibility. In: Using the Bartington MS2 System. England, British Library (104 pp.).

Delbari, M., Afrasiab, P., Loiskandl, W., 2009. Using sequential Gaussian simulation to assess the fi eld-scale spatial uncertainty of soil water content. Catena 79 (2), 163-169. http://dx.doi.org/10.1016/j.catena.2009.08.001.

Deutsch, C.V., Journel, A.G., 1998. GSLIB: Geostatistical Software Library: and User's Guide, second ed. Oxford University Press, New York (369 pp.).

Embrapa-Empresa Brasileira de Pesquisa Agropecuária, 1995. Centro Nacional de Pesquisa de Solos. In: Normative Procedures for Soil Surveys. Embrapa, Brasília (in Portuguese).

Embrapa-Empresa Brasileira de Pesquisa Agropecuária, 1997. Centro Nacional de Pesquisa de Solos. In: Manual of Soil Analysis Methods. Embrapa, Rio de Janeiro (in Portuguese).

Eswaran, H., Reich, P.F., 2005. World soil map. In: Hillel, Daniel (Ed.), Encyclopedia of Soils in the Environment. Elsevier, Amesterdã, pp. 352-365. http://dx.doi.org/10. 1016/B0-12-348530-4/00019-9.

Fekiacova, Z., Pichat, S., Cornu, S., Balesdent, J., 2013. Inferences from the vertical distribution of Fe isotopic compositions on pedogenetic processes in soils. Geoderma 209-210, 110-118. http://dx.doi.org/10.1016/j.geoderma.2013.06.007.

Fürst, C., Zirlewagen, D., Lorz, C., 2010. Regionalization of magnetic susceptibility measurements based on a multiple regression approach. Water Air Soil Pollut. 208 (1), 129-151. http://dx.doi.org/10.1007/s11270-009-0154-1.

Geobank-Serviço Geológico do Brasil-CPRM, 2014. http://geobank.sa.cprm.gov.br/, Accessed date: 15 April 2014 (in Portuguese).

Grunwald, S., Reddy, K.R., Prenger, J.P., Fisher, M.M., 2007. Modeling of the spatial variability of biogeochemical soil properties in a freshwater ecosystem. Ecol. Model. 201 (3-4), 521-535. http://dx. doi.org/10.1016/j.ecolmodel.2006.10.026.

Grunwald, S., Thompson, J.A., Boettinger, J.L., 2011. Digital soil mapping and modeling at continental scales: finding solutions for global issues. Soil Sci. Soc. Am. J. 75 (4), 1201-1213. http://dx.doi.org/10.2136/sssaj2011.0025.

Hanesch, M., Scholger, R., 2005. The influence of soil type on the magnetic susceptibility measured throughout soil profiles. Geophys. J. Int. 161 (1), 50-56. http://dx.doi.org/ 10.1111/j.1365-246X.2005.02577.x.

Hanesch, M., Rantitsch, G., Hemetsberger, S., Scholger, R., 2007. Lithological and pedological influences on the magnetic susceptibility of soil: their consideration in magnetic pollution mapping. Sci. Total Environ. 382 (2-3), 351-363. http://dx.doi. org/10.1016/j.scitotenv.2007.04.007.

Hengl, T., Jesus, J.M., Macmillan, R.A., Batjes, N.H., Heuvelink, G.B.M., Ribeiro, E. Samuel-Rosa, A., Kempen, B., Leenaars, J.G.B., Walsh, M.G., Gonzalez, M.R., 2014. SoilGrids $1 \mathrm{~km}$ - global soil information based on automated mapping. PLoS One 9 (12), e105992. http://dx.doi.org/10.1371/journal.pone.0105992.

Hengl, T., Jesus, J.M., Heuvelink, G.B.M., Gonzalez, M.R., Kilibarda, M., Blagotić, A., Shangguan, W., Wright, M.N., Geng, X., Bauer-Marschallinger, B., Guevara, M.A., Vargas, R., MacMillan, R.A., Batjes, N.H., Leenaars, J.G.B., Ribeiro, E., Wheeler, I., Mantel, S., Kempen, B., 2017. SoilGrids250m: global gridded soil information based on machine learning. PLoS One 12 (2), e0169748. http://dx.doi.org/10.1371/ journal.pone.0169748.

Hudson, B.D., 1992. The soil survey as paradigm-based science. Soil Sci. Soc. Am. J. 56 (3), 836-841. http://dx.doi.org/10.2136/sssaj1992.03615995005600030027x. 
Hutchinson, M.F., 1989. A new procedure for gridding elevation and stream line data with automatic removal of spurious pits. J. Hydrol. 106, 211-232. http://dx.doi.org/ 10.1016/0022-1694(89)90073-5.

IPT-Instituto de Pesquisas Tecnológicas do Estado de São Paulo, 1981. Geomorphological Map of the State of São Paulo. (94 pp.). (in Portuguese).

Isaaks, E.H., Srivastava, R.M., 1989. Applied Geostatistics. Oxford University Press, Nova York (561 pp.).

Jong, E., Nestor, P.A., Pennock, D.J., 1998. The use of magnetic susceptibility to measure long-term soil redistribution. Catena 32 (1), 23-35. http://dx.doi.org/10.1016/ S0341-8162(97)00051-9.

Jong, E., Pennock, D.J., Nestor, P.A., 2000. Magnetic susceptibility of soils in different slope positions in Saskatchewan, Canada. Catena 40 (3), 291-305. http://dx.doi.org/ 10.1016/S0341-8162(00)00080-1.

Kelley, J., Higgins, C.W., Pahlow, M., Noller, J., 2017. Mapping soil texture by electromagnetic induction: a case for regional data coordination. Soil Sci. Soc. Am. J. 81 (4), 923-931. http://dx.doi.org/10.2136/sssaj2016.12.0432.

Legros, J.P., 2006. Mapping of the Soil. Science Publishers, Enfield (411 pp.).

Maher, B.A., Alekseev, A., Alekseeva, T., 2003. Magnetic mineralogy of soils across the Russian steppe: climatic dependence of pedogenic magnetite formation. Palaeogeogr. Palaeoclomatol. 201 (3-4), 321-341. http://dx.doi.org/10.1016/S0031-0182(03) 00618-7.

Marques Jr., J., Siqueira, D.S., Camargo, L.A., Teixeira, D.D.B., Barron, V., Torrent, J., 2014. Magnetic susceptibility and diffuse reflectance spectroscopy to characterize the spatial variability of soil properties in a Brazilian Haplustalf. Geoderma 219-220, 63-71. http://dx.doi.org/10.1016/j.geoderma.2013.12.007.

Marques Jr., J., Alleoni, L.R.F., Teixeira, D.D.B., Siqueira, D.S., Pereira, G.T., 2015 Sampling planning of micronutrients and aluminium of the soils of São Paulo, Brazil. Geoderma Reg. 4, 91-99. http://dx.doi.org/10.1016/j.geodrs.2014.12.004.

Matias, S.S.R., Marques Jr., J., Siqueira, D.S., Pereira, G.T., 2013. Landscape models and magnetic susceptibility on soil identification and characterization. Pesqui. Agropec. Trop. 43 (1), 93-103 (in Portuguese).

Matias, S.S.R., Marques Jr., J., Siqueira, D.S., Pereira, G.T., 2014. Outlining precision boundaries among areas with different variability standards using magnetic susceptibility and geomorphic surfaces. Eng. Agric. 34 (4), 695-706. http://dx.doi.org/ 10.1590/S0100-69162014000400009.

Miller, B.A., Koszinski, S., Wehrhan, M., Sommer, M., 2015. Impact of multi-scale predictor selection for modeling soil properties. Geoderma 239-240, 97-106. http://dx. doi.org/10.1016/j.geoderma.2014.09.018.

Mirzaeitalarposhti, R., Demyan, M.S., Rasche, F., Cadisch, G., Müller, T., 2017. Mid-infrared spectroscopy to support regional-scale digital soil mapping on selected croplands of South-West Germany. Catena 149, 283-293. http://dx.doi.org/10.1016/j. catena.2016.10.001.

Montanari, R., Souza, G.S.A., Pereira, G.T., Marques Jr., J., Siqueira, D.S., Siqueira, G.M., 2012. The use of scaled semivariograms to plan soil sampling in sugarcane fields. Precis. Agric. 13 (5), 01-11. http://dx.doi.org/10.1007/s11119-012-9265-6.

Nanni, M.R., Dematte, J.A.M., Silva Jr., C.A., Romagnoli, F., Silva, A.A., Cezar, E., Gasparotto, A.C., 2014. Soil mapping by laboratory and orbital spectral sensing compared with a traditional method in a detailed level. J. Agron. 13 (3), 100-109. http://dx.doi.org/10.3923/ja.2014.100.109.

Odgers, N.P., McBratney, A.B., Minasny, B., 2015. Digital soil property mapping and uncertainty estimation using soil class probability rasters. Geoderma 237-238, 190-198. http://dx.doi.org/10.1016/j.geoderma.2014.09.009.

Phillips, J.D., 2013. Evaluating taxonomic adjacency as a source of soil map uncertainty. Eur. J. Soil Sci. 64 (4), 391-400. http://dx.doi.org/10.1111/ejss.12049.

Prado, H., 2013. Pedology - Applications for Tropical Soils. Produção Independente, Piracicaba (284 pp.). (in Portuguese).

Preetz, H., Altfelder, S., Igel, J., 2008. Tropical soils and landmine detection - an aproach for a classification system. Soil Sci. Soc. Am. J. 72 (1), 151-159.

Rogowski, A.S., Wolf, J.K., 1994. Incorporating variability into soil map unit delineations. Soil Sci. Soc. Am. J. 58 (1), 163-174. http://dx.doi.org/10.2136/sssaj1994. $03615995005800010024 x$

Santos, H.G., Jacomine, P.K.T., Anjos, L.H.C., Oliveira, V.A., Lumbreras, J.F., Coelho,
M.R., Almeida, J.A., Cunha, T.J.F., Oliveira, J.B., 2013. Sistema brasileiro de classificação de solos, third ed. Embrapa, Brasília.

Sarmast, M., Farpoor, M.H., Boroujeni, I.E., 2017. Magnetic susceptibility of soils along a lithotoposequence in southeast Iran. Catena 156, 252-262. http://dx.doi.org/10. 1016/j.catena.2017.04.019.

Sarmento, E.C., Giasson, E., Weber, E.J., Flores, C.A., Hasenack, H., 2017. Disaggregating conventional soil maps with limited descriptive data: a knowledge-based approach in Serra Gaúcha, Brazil. Geoderma Regional 8, 12-23. http://dx.doi.org/10.1016/j. geodrs.2016.12.004.

Schwertmann, U., 1985. The effect of environments on iron oxide minerals. Adv. Soil Sci. 1, 172-200. http://dx.doi.org/10.1007/978-1-4612-5046-3_5.

Silva, A.F., Pereira, M.J., Carneiro, J.D., Zimback, C.R.L., Landim, P.M.B., Soares, A., 2014. A new approach to soil classification mapping based on the spatial distribution of soil properties. Geoderma 219-220, 106-116. http://dx.doi.org/10.1016/j. geoderma.2013.12.011

Silva, A.F., Pereira, M.J., Zimback, C.R.L., Landim, P.M.B., Soares, A., 2015. Sequential simulation of diagnostic soil atributes. Rev. Bras. Eng. Agríc. Ambient. 19 (5), 418-425. (in Portuguese). https://doi.org/10.1590/1807-1929/agriambi v19n5p418-425.

Siqueira, D.S., Marques Jr., J., Matias, S.S.R., Barrón, V., Torrent, J., Baffa, O., Oliveira, L.C., 2010. Correlation of properties of Brazilian Haplustalfs with magnetic susceptibility measurements. Soil Use Manag. 26 (4), 425-431. http://dx.doi.org/10. 1111/j.1475-2743.2010.00294.x.

Siqueira, D.S., Marques Jr., J., Pereira, G.T., Barbosa, R.S., Teixeira, D.D.B., Peluco, R.G., 2014. Sampling density and proportion for the characterization of the variability of Oxisol attributes on different materials. Geoderma 232-234, 172-182. http://dx.doi. org/10.1016/j.geoderma.2014.04.037.

Siqueira, D.S., Marques Jr., J., Pereira, G.T., Teixeira, D.D.B., Vasconcellos, V., Carvalho Jr., O., Martins, E., 2015. Detailed mapping unit design based on soil-landscape relation and spatial variability of magnetic susceptibility and soil color. Catena 135, 149-162. http://dx.doi.org/10.1016/j.catena.2015.07.010.

Teixeira, D.D.B., Bicalho, E.S., Panosso, A.R., Perillo, L.I., Iamaguti, J.L., Pereira, G.T., La Scala, N., 2012. Uncertainties in the prediction of spatial variability of soil $\mathrm{CO}^{2}$ emissions and related properties. Rev. Bras. Ci. Solo 36 (5), 1466-1475. http://dx. doi.org/10.1590/S0100-06832012000500010.

Teixeira, D.D.B., Marques Jr., J., Siqueira, D.S., Vasconcelos, V., Carvalho Jr., O.A., Martins, E.S., Pereira, G.T., 2017. Sample planning for quantifying and mapping magnetic susceptibility, clay content, and base saturation using auxiliary information. Geoderma 305, 208-218. https://doi.org/10.1016/j.geoderma.2017.06.001.

Thornthwaite, C.W., 1948. An approach towards a rational classification of climate. Geogr. Rev. 38, 55-94.

USDA-Soil Survey Staff, 1999. Soil Taxonomy: a Basic System of Soil Classification of Making and Interpreting Soil Surveys, 2nd ed. USDA-Natural Resources Conservation Service, Washington (869 pp.).

Vasconcelos, V., Carvalho Jr., O.A., Martins, E.S., Couto Jr., A.F., Guimarães, R.F., Gomes, R.A.T., 2012. Geomorphometric classification system based on a two-stage sequentia architecture: decision tree and spectral classifier. In: The Serra Da Canastra National Park. Rev. Bras. Geomorf. 13. pp. 171-186 (2). (in Portuguese).

Vincent, S., Lemercier, B., Berthier, L., Walter, C., 2018. Spatial disaggregation of complex soil map units at the regional scale based on soil-landscape relationships. Geoderma 311, 130-142. https://doi.org/10.1016/j. geoderma.2016.06.006.

Viscarra-Rossel, R.A., Webster, R., Bui, E.N., Baldock, J.A., 2014. Baseline map of organic carbon in Australian soil to support national carbon accounting and monitoring under climate change. Glob. Chang. Biol. 20 (9), 2953-2970. http://dx.doi.org/10.1111/ gcb.12569.

Wu, Y., Slater, L., Versteeg, R., Labrecque, D., 2008. A comparison of the low frequency electrical signatures of iron oxide versus calcite precipitation in granular zero valent iron columns. J. Contam. Hydrol. 95, 154-167. http://dx.doi.org/10.1016/j.jconhyd. 2007.09.003.

Zhu, A.X., 1997. Measuring uncertainty in class assignment for natural resource maps under fuzzy logic. Photogramm. Eng. Remote. Sens. 63 (10), 1195-1202. 